\title{
Helena Grochola-SzCZePANEK
}

\section{JEZZYK POTOMKÓW POLSKICH OSADNIKÓW Z DERENKU NA WEGGRECH}

COBISS: 1.02

\section{Jezilk potomcev poljskih kolonistov v Derenku na Madžarskem}

$\mathrm{V}$ prispevku so predstavljene glavne značilnosti jezika potomcev poljskih kolonistov na Madžarskem. Avtorica analizira, koliko slovniški in slovarski pojavi ustrezajo poljskim narečjem. Podlaga za analizo so intervjuji z govorci poljske skupnosti na Madžarskem, posneti v letih 2013-2014.

Ključne besede: poljska skupnost na Madžarskem, podhalsko narečje, spiško narečje, mešani kod, jezikovne interference

\section{The language of descendants of Polish colonists from Derenk, Hungary}

This article presents the main features of the language of descendants of Polish colonists in Hungary. The author analyzes grammatical and lexical phenomenon to determine similarity with Polish dialects. Interviews with respondents from the Polish community in Hungary form the basis of the analysis. They were recorded in 2013 and 2014.

Keywords: Polish community in Hungary, Podhale dialect, Spisz dialect, mixed code, language interference

\section{WPROWADZENIE}

W 2014 roku ukazała się publikacja pt. Stownik gwarowy mieszkańców Derenku i ich potomków, będąca pracą zbiorową trojga regionalistów pochodzących ze Spisza (Kowalczyk - Kowalczyk - Łukuś 2014).1 Słowniczek jest rezultatem rozmów, jakie autorzy odbyli z byłymi mieszkańcami Derenku podczas kilku wizyt na Węgrzech w latach 2013-2014. W słowniczku jest około 1300 alfabetycznie ułożonych wyrazów oraz około 200 dłuższych form wypowiedzi, wyrażeń i zwrotów. Hasła podane są w zapisie ortograficznym z zachowaniem najważniejszych cech wymowy gwary derenczan. ${ }^{2}$ Książka zawiera także przewodnik w dwóch wersjach językowych: polskiej i węgierskiej, zawierający m.in. informacje o badaniach oraz zarys dziejów Derenku. Do książki dołączona jest płyta CD z plikami audio.

$1 \quad$ Projekt pt. Słownik gwarowy mieszkańców Derenku i ich potomków został zrealizowany dzięki międzynarodowej współpracy Stowarzyszenia Borsod-Torna-Gömör-Egyesület w Edelény na Węgrzech i Stowarzyszenia Rozwoju Spisza i Okolicy w Łapszach Niżnych.

2 Określenie derenczanie przyjęto tu umownie na grupę informatorów, wśród których są osoby urodzone w samym Derenku oraz innych miejscowościach po przesiedleniu. 
Głównym celem artykułu jest próba scharakteryzowania języka mieszkańców Derenku na podstawie materiałów zamieszczonych we wspomnianej pracy. Należy zaznaczyć, że analiza skupia się jednak nie na słowniczku, który jest już pewnego rodzaju interpretacją faktów językowych, lecz na samych nagraniach dźwiękowych, które stanowią pierwotny materiał źródłowy. Istotnym celem badań jest wydobycie cech gramatycznych języka nagranych informatorów oraz charakterystyka słownictwa, którym się posługują w celu określenia stopnia zachowania gwary podhalańsko-spiskiej.

\section{SKĄD NA WĘGRZECH POLSKA WIIEŚ?}

Derenk to niewielka średniowieczna osada położona w północno-wschodniej części Węgier, w historycznym województwie Torna, około $1 \mathrm{~km}$ od granicy ze Słowacją (obecnie województwo Borsod-Abaúj-Zemplén). Jej nazwa pochodzi od słowiańskiej nazwy deren, deryn, dren, drenka 'dereń', co pozwala domniemywać, że jej pierwszymi mieszkańcami byli Słowianie. Historia derenckiej osady jest ściśle powiązana z zamkiem Szárd lub Szád, do którego należała jako posiadłość królewska, później kolejno rodu Bebeków, hrabiów Csáki, książąt Esterházych. Po wyburzeniu zamku przyjęła jego nazwę, stając się szadvarskim dominium. Od 1986 roku wieś trafiła do majątku Andrassych, a od 1936 stała się własnością Węgierskiego Skarbu Królewskiego.

Panująca w 1711 roku epidemia cholery spustoszyła zamieszkałą przez Węgrów osadę. Większość mieszkańców zmarła, a pozostali uciekli w obawie przed chorobą. Przez kilka lat Derenk pozostawał miejscem całkowicie opuszczonym i wyludnionym. Dzięki spontanicznemu osadnictwu oraz zorganizowanej akcji osiedleńczej prowadzonej przez Esterházych, do Derenku przybyła ludność pochodzenia polskiego i zamieszkiwała w tej miejscowości od 1717 do 1943 roku. 3 Według ustaleń historyków, osadnicy pochodzili z terenu Podhala i Spisza, a głównie z trzech miejscowości: Białki Tatrzańskiej, Bukowiny Tatrzańskiej oraz Czarnej Góry (Rémiás 2009).

W latach 30. XX wieku władze węgierskie podjęły uchwałę o utworzeniu terenów łowieckich wokół Derenku, a tym samym zdecydowały o wysiedleniu całej wsi. Ostateczną akcję przesiedleńczą zrealizowano w 1943 roku. W Derenku zamieszkiwało wówczas około 450 mieszkańców. Ponad połowa wsi, pięćdziesiąt rodzin (ok. 250 osób) została przesiedlona do pożydowskiego folwarku Istvánmajor, o którym zaczęto później mówić jako o »polskiej wsi na Węgrzech«. Po dwadzieścia rodzin przemieszczono do osad Andrástanya i Sajószentpéter, dziesięć rodzin - do Büdöskútpuszta. Osady Andrástanya i Istvánmajor były

3 O zaludnieniu osady przez Polaków mają świadczyć dokumenty Archiwum Państwowego, których fragmenty z 1719 i 1723 roku podaje M. Hemmert. Występują tam nazwiska polskich osadników m.in. Bubenik, Juhasz, Koczur, Kovacs, Krakovszki, Mlinar, Remias, Vargha (Hemmert 1971: 86). 
wcześniej wyludnione, powstały zatem dwie nowe mniejsze polskie miejscowości, jednak mniej odizolowane od środowisk węgierskich niż Derenk. Pojedyncze rodziny osiedliły się także we wsiach: Emöd, Körtvélyes (obecnie na Słowacji), Ládbesenyő, Martonyi, Szendrő, Szögliget, Vatta (por. Rémiás 2009). Elementy zabudowy z Derenku zostały przewiezione na nowe miejsca przesiedleńców, a pozostałości wyburzone przy pomocy specjalnych służb. W świadomości przesiedlonych mieszkańców i ich potomków nie zanikło jednak poczucie wspólnoty. Do tej pory spotykają się w Derenku podczas dorocznego odpustu przy małej kaplicy wybudowanej w miejsce wyburzonego kościoła.

\section{DERENK W BADANIACH}

Na temat migracji ludności polskiej na południową stronę Karpat oraz polonii węgierskiej powstało wiele prac polskich, słowackich i węgierskich historyków, etnografów oraz językoznawców. Wśród opracowań historycznych ważne miejsce zajmują monografie Tibora Rémiása, zawierające między innymi wnikliwą analizę ksiąg metrykalnych mieszkańców Derenku z lat 1724-1942, dzieje osady od średniowiecza, a szczególnie lata 1717-1842, kiedy mieszkali polscy osadnicy (Rémiás 2004; 2005; 2007; 2009). Zagadnieniom migracji ludności polskiej na teren Górnych Węgier poświęcone są prace Mieczysława Małeckiego (1938) i Marka Gotkiewicza (1962). Badania etnograficzne dotyczące m.in. związków kulturowych pomiędzy Polakami, Słowakami i Węgrami, struktury osadnictwa polskiego, stanu gospodarki, kultury materialnej, społecznej i duchowej przedstawia dwutomowe opracowanie Potomkowie osadników z Polski we wsiach Derenk i Istvánmajor na Węgrzech (Kantor - Krasińska 1981).

Pierwsze wzmianki na temat języka mieszkańców Derenku odnajdujemy w pracy Nárečie troch slovenských ostrovov v Mad'arsku, w której autor scharakteryzował badaną mowę jako gwarę podhalańską (Štolc 1949). Ważną publikacją dotycząca języka derenczan jest opracowanie Marii Hemmert pt. Gwara polska wsi Emöd-Istvánmajor na Wegrzech (Hemmert 1971), będące niepublikowaną pracą doktorska, jej maszynopis znajduje się w archiwum Uniwersytetu w Szegedzie. Sytuację polskiej gwary we wsi Istvánmajor oraz wpływy języka węgierskiego autorka przedstawiła także w późniejszych artykułach publikowanych w polskich czasopismach (Hemmert 1971; 1972). Zbadany język autorka określiła jako gwarę polską z przewagą cech spiskich. Wśród opracowań językoznawczych warto wymienić monografię Wiesława Stefańczyka pt. Język Polonii węgierskiej: ujęcie typologiczne, w której autor omawia głównie zagadnienia morfologiczne i składniowe (Stefańczyk 1995). Tematyka związana z polską gwarą na Węgrzech była poruszana także w artykułach m.in: Zenona Stiebera (1950), Janusza Reychmana (1956; 1964), Kazimierza Dejny (1992), Elżbiety Artowicz (1997), Bubenko-Greszkó (1998).

Jak wynika z badań, mieszkańcy Derenku (pokolenie starsze i średnie) posługiwali się na co dzień polską gwarą jeszcze w latach 60. ubiegłego wieku (por. 
Hemmert 1971). Najdłużej polski charakter językowy zachowała wieś Istvánmajor. W latach 90. XX wieku liczba czynnych użytkowników gwary ograniczyła się do najstarszego pokolenia (por. Stefańczyk 1995). Jak wynika z najnowszych ustaleń, obecnie jest około 20 najstarszych mieszkańców, którzy są w stanie posługiwać się polską gwarą (Stefańczyk 2013: 481). Młodsze pokolenia posiadają tylko bierną znajomość gwary. W codziennej komunikacji dawnych mieszkańców Derenku i ich potomków dominuje już język węgierski.

\section{CHARAKTERYSTYKA NAGRAŃ}

Materiał dźwiękowy zawarty na płycie CD dołączonej do słowniczka to około 2 godzin nagrań różnego typu: śpiewu, śpiewu z muzyką, rozmów, opowiadań, dialogów i monologów. Nagrania podzielone są na 11 części tematycznych:

[1] Drenka Polska - śpiew

[2] Drenka Polska - śpiew i muzyka

[3] Inne teksty i pieśni w wykonaniu informatorów

[4] Charakterystyka wsi Derenk, życie mieszkańców i ich potomków

[5] Gospodarka wsi Derenk i Andrastanya (rolnictwo, hodowla, pasterstwo, gospodarka leśna, praca zarobkowa poza własnym gospodarstwem rolnym)

[6] Obrzędy i zwyczaje rodzinne (narodziny, wesele, pogrzeb)

[7] Świat dziecka - szkoła, zabawy, tragedie

[8] Obrzędy i zwyczaje doroczne, zabawa i magia (andrzejki, wigilia, Boże Narodzenie, Wielkanoc)

[9] Wiara, wierzenia, medycyna

[10] Problemy derenczan związane z przesiedleniem i aklimatyzacją w nowym środowisku

[11] Pozostałe materiały

Dwie pierwsze części zawierają pieśni w wykonaniu zespołu artystycznego Drenka Polska, prowadzonego przez potomkinie mieszkańców Derenku. W repertuarze zespołu są pieśni, które były znane i śpiewane jeszcze przez samych mieszkańców Derenku oraz nowsze, powstałe pod koniec ubiegłego wieku. Warto przytoczyć kilka charakterystycznych tytułów pieśni: Dejcie ze mi dejcie, Idzie diabol od Jurgowa, Niedaleko Corna Góra Jurgowa, Od Krakowa, Syroko je tota woda, Tańcuwala by jo. W części trzeciej zawarte są pieśni, wiersze oraz inne teksty w wykonaniu informatorów. Kolejne części (4-11) zawierają wypowiedzi informatorów na tematy, które noszą odpowiednie tytuły, np. Opis domu, gospodarstwa, Praca na gospodarce w Derenku, Pożywienie, Pieczenie chleba, Krosna - przygotowanie, praca, Wróżby andrzejkowe, Psoty Teresy w szkole. Przy tytułach podane są dane o informatorach oraz czasie trwania każdego nagrania.

Wywiady zostały przeprowadzone z 20 informatorami w 5 miejscowościach: Andrástanya, Ládbesenyő, Istvánmajor, Emöd i Sajószentpéter. Jak wynika 
z wykazu informatorów, 7 rozmówców to osoby urodzone w latach 1922-1940 w Derenku. Pozostała grupa rozmówców to osoby urodzone pomiędzy rokiem 1945 a 1959, czyli już po przesiedleniu do innych miejscowości (Kowalczyk - Kowalczyk - Łukuś 2014: 75).

Nagrania są dość dobrej jakości. Niekiedy występuje nakładanie głosów oraz używanie wyrazów węgierskich, czy wręcz przechodzenie na język węgierski, co utrudnia zrozumienie wypowiedzi. Wszystkie nagrania, poza fragmentami niepewnymi i trudnymi do zidentyfikowania, zostały odsłuchane i zapisane w wersji ortograficznej przez autorkę tego tekstu w celu analizy języka derenczan.

\section{CECHY JEZZYKA DERENCZAN}

W nagranych rozmowach z byłymi mieszkańcami Derenku z łatwością odnajduje się cechy charakterystyczne dla gwar południowomałopolskich, a szczególnie podhalańskiej i spiskiej. Są to m.in. mazurzenie, archaizm podhalański, wymowa samogłosek nosowych i pochylonych. Uwidaczniają się także wpływy języka słowackiego oraz węgierskiego. W zapisanych nagraniach uwagę zwracają liczne wahania dotyczące określonych cech, często występujące nawet w wypowiedzi jednego informatora. Przyjrzyjmy się zatem dokładniej poszczególnym cechom języka derenczan.

\subsection{Mazurzenie}

Jedną z głównych cech języka, którym posługują się nagrani informatorzy jest mazurzenie, czyli wymowa spółgłosek dziąsłowych $s z, \dot{z}, c z$ jako przedniojęzykowo-zębowych $s, z, c$, np. borsc 'barszcz', cekali 'czekali', koloc 'kołacz', kurcyntka 'kurczątka', na omse 'na mszę', nie kupis 'nie kupisz', oci 'oczy', peśnicki 'piosenki', slozyla 'złożyła', wcora 'wczoraj', wyscyryla 'wyszczerzyła'.

Głoska $s z$ bywa wymawiana jako środkowo-językowe ś, np. śli 'szli', ślimy 'szliśmy', śtuchali 'tu: dotykali', śtyraceć 'czterysta', śtyrók 'czterech', w kaśtelu 'w kasztelu'.

Występują także głoski $c z, s z, \dot{z}$, których obecność należy tłumaczyć jako wpływ języka słowackiego lub węgierskiego, np. aposztoli 'apostołowie', czołno 'czółno', iszli 'poszli', Pilatusz 'Piłat', szablicka 'szabelka', szafel 'szaflik', szalata 'sałata', sziatry 'stragany', sziednol 'usiadł', szionka 'szynka', szpule, sztołek 'krzesło', taszka 'torba', żarla 'jadła', żena 'kobieta', żupki 'strzechy ze słomy'.

W licznej grupie wyrazów występują wahania w obrębie szeregów $s z, \dot{z}, c z$ i $s, z, c$, np. cereśnie / czereszienki 'czereśnie', fszelijaki / fselijaki 'rozmaity', koszol / kosol 'kosił', ne mozes 'możesz' / możem 'mogę', penaże / pieniaże / penadze 'pieniądze', priszli / priśli 'przyszli', seś / szest 'sześć', sitko / szicko / szitko 'wszystko', sztiri / śtyry 'cztery', szumna / sziumna / siumna 'piękna', w 
Miszkolcu / Miskolcu, żelóny / zielóny 'zielony'. Niekiedy wahania dotyczą jednego szeregu, np. wyraz czwartek występuje w trzech wariantach: cwortek, swortek $i$ scwortek.

\subsection{Archaizm podlhalański}

W języku derenczan zachowała się pierwotna samogłoska $i$ w kontynuantach dawnych prasłowiańskich połączeń: ${ }_{s z}^{*} i, *_{z} i,{ }^{*} c z ’ i$, w których spółgłoski dziąsłowe $c z, \dot{z}, s z$ uległy następnie mazurzeniu (w języku ogólnym w tej pozycji y od XVI w.). Samogłoska $i$ nie zmiękcza tu poprzedzającej spółgłoski, np. chlopci 'chłopcy', cija 'czyja', ciście 'czyście', jak oboci 'jak zorientuje się', jynzik 'język', mocidlo 'sztucznie utworzony zbiornik wody do moczenia lnu; moczydło', nojraci 'najbardziej', ociska 'oczyska', odpatrim 'odpatrzę', parobci 'kawalerowie', piyrsi 'pierwsi', pri 'przy', porwozi 'powrozy', pridź 'przyjdź', róuzicka 'różyczka', śpywajynci 'śpiewając', Zidzi ‘Żydzi'. Taka wymowa rozszerzyła się także w wyrazach z połączeniami: sy, zy, cy, np. cifrówana 'ozdobiona wzorami', kołoci 'kołaczy', sin 'syn', sinowie 'synowie', włosi 'włosy'.

Po spółgłoskach $s z, \dot{z}, c z, r z$, ale przed $r$ nie występuje $i$, lecz $y$, np. cyrwóny 'czerwony', syroki 'szeroki', wyscyryla 'wyszczerzyła'.

\subsection{Akcent inicjalny}

Informatorzy akcentują zwykle pierwszą sylabę. Można mówić tu o zachowaniu akcentu inicjalnego charakterystycznego dla gwary podhalańskiej i spiskiej. W podtrzymaniu tej cechy na pewno pomógł język węgierski, w którym także występuje akcent na pierwszą sylabę. W nagraniach słyszymy zatem przykłady: kr/acunske 'bożonarodzeniowe, od wyrazu Kracun 'Boże Narodzenie', M/aria, d/o_lasu, p/otrepały 'potrzepały', p/o_połedniu 'po południu', w/ybralimy 'wybraliśmy'.

\subsection{Występowanie spółgłoski $r$ w miejsce $r z$ oraz $r$ frylkatywnego}

Jest to cecha konsekwentnie występująca w mowie derenczan, np. burić 'tłuc', drewo 'drzewo', dobre 'dobrze', do ryftora 'do wójta', gwarić 'gwarzyć, mówić', hrynu 'chrzanu', jarec 'jęczmień', marec 'marzec', na kriz pribiyli 'na krzyż przybili', okuróne 'wędzone', ottar 'ołtarz', ore 'orze', orechami 'orzechami', otworcie 'otwórzcie', po bruchu, pogryb 'pogrzeb', predali 'sprzedali', pridź 'przyjdź', priszli 'przyszli', popatrij sie 'popatrz się', pri weceri 'przy wieczerzy', redke 'rzadkie', retiazka 'łańcuch', rezali 'rzezali, cięli', streliła 'strzeliła', tri ‘trzy', strigi 'strzygi', tristo 'trzysta', wrecióno 'wrzeciono'. Zastapienie głoski rz przez $r$ jest wyraźnym wpływem języka słowackiego.

Głoska $r z$ pojawiła się w nagraniach w czterech następujących wyrazach: jaworze, prziprawić 'przyprawić', dobrze, na dworz (ale na dwore 'na podwórku’). Dwa pierwsze przykłady pochodzą z pieśni, a dwa kolejne z wypowiedzi informatorów. 
Poza tym twarde $r$ występuje normalnie w gwarze derenczan, np. chory, z cukrem, drewiany 'drewniany', grod 'grad', kradli, kuri 'kury', na drugi rok, portki, rajbali 'prali', role, rombać 'rąbać', skarol 'pokarał', skrobala sie 'drapała się', sikiera 'siekiera'.

\subsection{Realizacja głosek $l$ i $l$}

Głoska welarna $t$ brzmi zasadniczo jako dźwięk nieco zmiękczony, pośredni pomiędzy $l$ a $t$, np. bylo 'było', maly 'mały', priwionzala falat plotna 'przywiązała kawałek płótna', widziala 'widziała'. Wyraźniej $t$ zaznaczyło się w wyrazach: cłomiana 'słomiana', gałynzie 'gałęzie', ołtar 'ołtarz', ościelyły 'pościeliły', po połedniu 'po południu', pyndziałek 'poniedziałek', zapolyły 'zapaliły'. Często występują wahania, np. była / byla, kolo, ale dookoła, młode / mlode, skoła / skola, włozyłak 'włożyłam' / wlozyli.

Głoska $l$ wymawiana jest neutralnie głównie w wyrazach węgierskich, np. langos 'placek', Laslo 'Władysław', lewes 'zupa', grekokatolikus. W wyrazach polskich słychać zarówno neutralne $l$, jak i zmiękczone l', np. chlyb 'chleb', ale chl'eby, kowol 'kowal', ale kowol'u. Warto zaznaczyć, że zarówno głoska $t$ jak i $l$ zmiękczone nie są znane w języku węgierskim.

\subsection{Występowanie głosek $g$ i $h / c h$}

Głoska g jest zachowana w mowie derenczan, np. drugi, głowa, gwarili 'gwarzyli, mówili', nogi. W wyrazach słowackich występuje głoska $h$, np. bohata 'bogata', hore 'w górę', hruby 'gruby', huszki 'gęsi', uhle 'węgle', zohrada 'zagroda'. Głoska $h$ realizowana jest dźwięcznie w nagłosie, np. herbet 'grzbiet', hlopci 'chłopcy', hejza 'dom, chałupa', hetka 'gdzieś', huncut 'łobuz' oraz w śródgłosie, np. betlehymki 'szopki bożonarodzeniowe', pohnut 'pachniał', truhla 'trumna', uho 'ucho', wahinka 'wanienka'. Palatalne $h$ ' wystapiło tylko w wyrazach hibaj 'chodź' oraz hipnót, prehipła (od hipnqć 'skoczyć, podskoczyć). Wygłosowe -ch realizowane jest jako - $k$, np. $d$ wok 'dwóch', na krosnak 'na krosnach', trik 'trzech', $w$ biolik 'w białych', $w$ cornyk smatak 'w czarnych szmatach'.

Nagłosowa grupa $c h c, c h w$ brzmi jako $f$, np. fciol (sporadycznie - jako $k$ : kciol) 'chciał', fce 'chce', fała 'chwała', także w śródgłosie grupa cht wymawiana jest jako $f$, np. plafta 'płachta'.

\subsection{Samogłoski pochylone}

Gwara mieszkańców Derenku zachowuje kontynuanty samogłosek pochylonych $a, o, e$. Samogłoska $a$ wymawiana jest jako głoska $o$, np. bioly 'biały', downe 'dawne', godol 'gadał', pleciyniok 'rodzaj chałki drożdżowej'. Głoska o brzmi jako dźwięk pośredni pomiędzy samogłoską o i u, np. óni, piecóne 'pieczone', zrobióne 'zrobione', zwóniyla 'dzwoniła'. Pochylona samogłoska $e$ realizowana jest jako y, np. dziywki 'dziewki', śpiywali 'śpiewali', gniyść 'gnieść'. Występują także jasne samogłoski, np. dobra, gadas 'gadasz', jemu, taka, temu. 


\subsection{Wymowa samogłosek nosowych}

Głoska nosowa $e$ w śródgłosie realizowana jest jako połączenie samogłoski ustnej $y+$ spółgłoska nosowa $m, n$, np. cielynta 'cielęta', dziywcynta 'dziewczęta', gałynzie 'gałęzie', kolymbka 'rodzaj kołyski, w której spało niemowlę podczas prac polowych', myndzi 'między', myndlica 'międlica', pamiyntom 'pamiętam', pryndli 'przędli', zakrynciyli 'zakręcili'. Wyjątkami są: bedem / bede 'będę', bedzie / budzie 'będzie', mieso / miyso 'mięso', petnac 'piętnaście', piać 'pięć', wiakse z wiaksymi 'większe z większymi'. W wygłosie e pozbawione jest nosowości, np. babe 'babę', sie / szie 'się', slome 'słomę'.

Głoska nosowa $a$ realizowana jest w śródgłosie jako połączenie samogłoski ustnej $o+$ spółgłoska $m, n$, np. monke 'mąkę', powiónzala 'powiązała', priciongli 'przyciągnęli', świyklónce 'błyszczące', zakónsić 'zakąsić - zagryźć'. Spotykamy także realizację $a$ jako $a$ lub $u$, np. $w$ miesiacu 'w miesiącu', penaże / pieniaże / penadze 'pieniądze', susiedowi 'sąsiadowi', za muz 'za mąż', wuski 'wąski' W wygłosie - $q$ brzmi jako -om, np. chustkóm 'chustką', kefom 'kefą-szczotką', dajóm 'dają', pod pazuchóm 'pod pazuchą, pod pachą', takom 'taką', tancujóm 'tańcują', zbyrkajóm 'zbyrkają-dzwonią'.

\subsection{Miękkość spółgłosek}

Spółgłoski miękkie: $k^{\prime}, g^{\prime}, p^{\prime}, b^{\prime}, v^{\prime}, m^{\prime}, n^{\prime}$ zachowują zwykle miękkość, np. kiedy, kniaziowi, Margieta 'Małgorzata', miesioncek 'księżyc', obłockiem 'obłoczkiem', pieniaże 'pieniądze', Remiasz, szickie 'wszystkie', takiego, wiecór 'wieczór', zaświeciół 'zaświecił', z Belgium 'z Belgii', ciynske 'ciężkie'. Występuje także twarda wymowa, którą można uznać za wpływ języka słowackiego, np. katolicke 'katolickie', ked 'kiedy', makem 'makiem', syroke 'szerokie', take 'takie', takego 'takiego', w nedziele 'w niedzielę', welki 'wielki', welkego.

\subsection{Uproszczenia grup spółgłoskowych}

Grupy spółgłoskowe ulegają uproszczeniom w nagłosie, np. dzie 'gdzie', dzieś 'gdzieś' oraz w wygłosie, np. puś 'puść', seś ‘sześć', kłaś 'kłaść', plyś 'pleść'. Obok tego występują także realizacje całych grup spółgłoskowych zarówno w nagłosie, np. gdzie, gdzieś, jak i w wygłosie, np. iść, jeść, prinieść ‘przynieść', wlyść ‘wleźć'.

\subsection{Spółgłoski protetyczne}

W nagraniach nie słychać elementów protetycznych w nagłosie typu Jewa 'Ewa', łokno 'okno', huzda 'uzda'. Raz tylko wystąpiło zjawisko labializacji w wyrazie włojna 'wojna'.

\subsection{Fleksja rzeczownika, przymiotnika, liczebnika, zaimka}

W końcówkach fleksyjnych w miejsce $-c h i-w$ występuje spółgłoska $-k$ w następujących przypadkach: D lm rzeczowników, np. chłopcók 'chłopców', sinók 'synów', w Msc lm rzeczowników, np. na krosnak 'na krosnach', w Kosicak 
'w Koszycach', w smatak 'w szmatach' oraz w D i Msc lm przymiotników, liczebników, zaimków, np. biolik 'białych', cornyk 'czarnych', na nik 'na ich', ónyk 'tych', tyk, dwok 'dwóch', trik 'trzech'.

Rozszerzenie zakresu użycia końcówki -ów (przy przejściu $-w>-k$ ) obserwuje się także w D lm, np. bratók 'braci', ciastók 'ciast', nicielnicók 'nicielnic', deskók'desek', dzieciók 'dzieci', smatók 'szmat'.

Nieregularne występują końcówki - $a$ i - $u$ w D lp, np. do roka 'do roku', $w$ dóma 'w domu', ale do lasu; podobnie końcówki -owi i - $u$ w C lp w jednosylabowych rzeczownikach rodzaju męskiego, np. bratowi / bratu, a także -ami $i-m i \mathrm{w}$ $\mathrm{N}$ lm, np. bratami 'braćmi', ale dziećmi, z krowmi 'z krowami'.

\subsection{Fleksja czasownilka}

W czasie teraźniejszym i przyszłym formy koniugacyjne mają końcówki: 1 os lp: -m, np. bedem / bede 'będę', chodzim 'chodzę', gwarim 'gwarzę, mówię', idem 'idę', mom 'mam', nie możem / mozym 'nie mogę', pamiyntom 'pamiętam', śpiywóm 'śpiewam', widzim 'widzę', wiym 'wiem', wybierem 'wybiorę'; 1 os 1m: -me lub -my, np. boime sie 'boimy się', idyme lub idymy / idemy 'idziemy', uwidime 'uwidzimy', zabijeme 'zabijemy'.

W czasie przeszłym w 1 os lp występuje końcówka z głoską - $k$, np. nakladlak 'nakładłam', pobośkalak 'pocałowałam', łapiółek 'złapałem', gwarilak 'gwarzyłam, mówiłam' lub forma równa 3 os lp, np. (ja) kosol 'kosił', zarosol 'zrosił', sie gniewala 'gniewała się', sie narodziyla 'narodziła się', śpiywala 'śpiewała', sie wydala 'wyszła za mąż', wleła 'wlała'. Końcówka z głoską - $k$ jest ruchoma i niekiedy w wypowiedziach występuje z innymi częściami mowy, np. jagek (jak + ek) huziala ‘jak kołysałam', jok (ja + k) sanuwala 'szanowałam', fsek sie skrobala (wsze 'zawsze' + k) 'zawsze się drapałam', jo wtedyk (wtedy + k) widzol 'wtedy widziałem', tagek (tak + ek) plakala 'tak płakałam’. Podobnie w 1 os lm występują formy w dwóch wariantach: gwarilimy, jedlimy, musielimy, wyspalymy lub tożsame z 3 os, np. (my) gwarili, iszli, priszli, spaly.

\subsection{Przysłówki, przyimki, zaimki, modulanty}

Wśród przysłówków i zaimków występują charakterystyczne formy, m.in. zakończone na -o, np. kielo / kelo 'ile', telo 'tyle'; -k, np. tamok 'tam' (obok także stamać / tamać), tutok'tutaj', pożyczone z języka słowackiego, np. daco 'coś', dafte$d y$ 'wtedy', dafto 'ktoś', dakedy 'kiedyś' oraz inne, np. hetka 'gdzieś, daleko', ka 'gdzie', nazod 'z powrotem', pokla / zakla 'zanim, dopóki'.

$\mathrm{W}$ przyimkach $w, z$ występuje tzw. e ruchome, np. we siórcu 'w fartuchu', we plafte 'w płachtę, we skole 'w szkole', we welki pióntek 'w wielki piątek', we wodzie, ze babciom. Znajdujemy także zjawisko podwajania przyimków i zaimków, np. ze z kosami, ze z malutkóm 'z malutką', ze z nami 'z nami', tota 'ta', toto 'to'.

W nagranych tekstach występują charakterystyczne modulanty: $k a, t a, n p .:$ 
Dziś ka wyśmiejom takiego.

A potym ka ludzie jeździyli zaś drewa rómbać.

Ta sie ześli do gwary.

Kie my pośli tam do skoly rano, ta tra bylo sie modlić.

\subsection{Charakterystyczine konstrukcje i połączenia wyrazów}

Zachowaną konstrukcją jest pluralis maiestaticus, czyli użycie liczby mnogiej, kiedy mowa jest o osobie starszej, np.:

Rano moja mamka stanyli o tretij.

Moja mać mie wynieśli na stonko.

Ociec tam kosiyli koło niego.

Stari ociec mali takie biole gacie.

Obok tego funkcjonują formy w liczbie pojedynczej typu: ociec siednot, matka niesta.

Występują także połączenia wyrazowe, mające określone znaczenie. Oto kilka przykładów:

- czasownik znać + dowolny bezokolicznik w znaczeniu 'umieć, potrafić coś robić', np. mój hłop, to juz tak znot śpiewać 'umiał śpiewać'; on nie zno ciganić 'on nie potrafi oszukiwać',

- czasownik tapić się + dowolny bezokolicznik w znaczeniu 'zacząć coś robić', tapiolek sie płakać, ze moja mać be w telewizjom; mamka tapiyli się gniyś ciasta,

- $\mathrm{rad} / \mathrm{rada}$, rade / radzi + czasownik widzieć w odpowiedniej formie osobowej w znaczeniu 'lubić', np. bars radzi mie widzieli, tego rada widzim,

- mieć najracy 'lubić bardzo', np. bo jo cie Janicku nojraci mom.

\subsection{Lelksyka gwarowa i zapożyczona}

Język mieszkańców Derenku pozbawiony wpływu polszczyzny literackiej, zachował wiele archaicznych nazw, które funkcjonują do tej pory także w gwarze podhalańskiej i spiskiej, np. bywać 'mieszkać, dedina / dziedzina 'wieś', dogwarać sie 'porozumieć się z kimś; dogadać się', dziywka 'panna', miano 'imię', krzesnomatka 'matka chrzestna', krzesny 'ojciec chrzestny', miesióncek 'księżyc', narobiać 'robić coś stale' ( $z$ dziećmi narobiali), narodzić sie 'urodzić się' (jo sie tam narodziyta), na zadek 'do tyłu', odpytuwać 'żegnać się' (parobek sie odptuwol od frajerki), odziewać 'ubierać', odzieci 'ubrani', parobek 'kawaler', raduwać się 'cieszyć się,, rajbać 'prać', siurc 'fartuch', statki 'krowy', świekier, wydawać sie 'wychodzić za mąż' (ona by sie wydawala), wadzić sie 'kłócić się', zwyki 'zwyczaje', zawreć 'zamknąc', zapowiqzać 'powiązać' (hebojcie mi zapowiqzać statki), zawarty 'zamknięty', zbyrkać 'wydawać dźwięk; dzwonić'.

$\mathrm{W}$ tworzeniu form zdrobniałych zauważa się udział charakterystycznych formantów dla gwary podhalańskiej, np. -iczka, -ućki, -yczek (malućki 'malutki', wodzicka 'woda', wiyrsycek' 'wierch'). 
Wśród czasowników charakterystyczną grupę tworzą formy zakończone na -uwać, np. frystykuwać 'jeść frystyk, czyli śniadanie', maluwać 'malować', plotkuwać 'plotkować', porusuwać 'ruszać czymś przez jakiś czas', raduwać sie 'cieszyć się', zakukuwać 'zaglądać'.

Wielokrotnie w wypowiedziach informatorów wystąpił czasownik onacić, będący zamiennikiem zastępującym inne czasowniki i przybierającym różne znaczenia, np. sztiri dzieci odónacol 'tu: wychował', wopno onacić 'tu: gasić', to fse bylo wyonacóne 'tu: uzgodnione'.

Niektóre leksemy w gwarze derenczan nabrały nowego znaczenia. Takim przykładem jest wyraz zdrówkać. W gwarze podhalańskiej i spiskiej wyraz ten oznacza 'mówić >na zdrowie` przy piciu alkoholu', natomiast w mowie derenczan - 'pozdrawiać', np.:

Kazdemy treba zdrówkać.

Ked starego raz esce uwidimy, a nie bedymy zdrówkać, tak na drugi dzień dostaniymy patyckiym.

Innym przykładem zmiany znaczenia jest czasownik nieść, który oprócz podstawowego znaczenia, występuje także w znaczeniu 'wieźć', np.:

Kie bars chory byt, wolali orwosia, abo na woz go połozyli i nieśli na wozie.

Ociec nieśli drewa na wozie.

Konopie odnieśli potym ka do stympók.

Od wyrazu sonki 'sanki' został utworzony czasownik sónkać sie 'jeździć na sankach': ked my sie iszli sónkać.

W zbiorze leksyki, którą wydobyto z nagrań duży udział ma słownictwo zapożyczone z języka słowackiego, np. bohata 'bogata', bośkać 'całować', ciźmićki 'buty', dafto 'ktoś', frajer 'narzeczony', frajirka / frajerka 'narzeczona', haicek 'gaj', haluszki 'kluski', huszki 'gęsi', hudobna 'biedna', lym 'tylko', omsa 'msza', szablicka 'szabla', sziumna 'ładna'.

W grupie słownictwa znajdują się nazwy zapożyczone z języka węgierskiego, np. bardo 'element warsztatu tkackiego', barsiun 'aksamit', baciar 'hulaka', gróf 'hrabia', hotar 'granica', kielcik 'wydatek', siuhaj 'kawaler'. W wypowiedziach informatorów zwracają uwagę wyrazy o rdzeniach węgierskich, do których dodawane są polskie końcówki, np. atelepituwać, otelipituwal < letelepitése 'przesiedlić', za estergajosza < esztergályos 'tokarz'.

Zebrane słownictwo nie wykazuje dużego zróżnicowana pod względem leksykalnym. Tylko nieliczne desygnaty mają warianty leksykalne, np. dziewcynta / dziywki, familia / rodzina, gadać / gwarić, lendelski / polski, madziarski / uherski / wegierski, mać / matka / mama / maminka, stary ociec / dziadek, stara mać / babcia, sziuhaj / parobek, śpiewanka / peśnicka, wydawać sie / iść za muz. 


\section{Podsumowanie}

Analiza gramatyczna i leksykalna nagranych rozmów z byłymi mieszkańcami Derenku skłania do kilku ogólniejszych konkluzji.

Po pierwsze, język derenczan z całą pewnością jest polską gwarą południowomałopolską. Nie ma powodu rozstrzygać, czy podhalańską, czy spiską, gdyż różnice pomiędzy gwarą tych trzech miejscowości, z których przybyli osadnicy, są marginalne. Za podhalańsko-spiską genealogią przemawia wiele przedstawionych powyżej cech języka derenczan, m.in. mazurzenie, archaizm podhalański, akcent inicjalny, wymowa samogłosek pochylonych i nosowych, obecność spółgłoski $-k \mathrm{w}$ zakończeniach fleksyjnych rzeczownika, przymiotnika, liczebnika, zaimka i czasownika oraz bezokolicznikowy formant -uwać. Gwara derenczan obfituje w leksykę charakterystyczną dla regionu Podhala i Spisza. Odnajdujemy tu wiele starych formacji, funkcjonujących po dziś dzień w gwarze podhalańskiej i spiskiej, np. dziedzina, miano, ka, krzesnomatka, podnozaje, parobek, świekier, zazbyrkać.

Po drugie, wyniesiona gwara przed trzema wiekami gwara podhalańsko-spiska i pozostająca pod wpływem języka słowackiego i węgierskiego stała się swoistym kodem mieszanym. Duży wpływ na gwarę derenczan miał język słowacki ze względu na bliskie sąsiedztwo i łatwe nawiązanie kontaktów ludźmi mówiącymi podobnym językiem, w przeciwieństwie do niezrozumiałego języka węgierskiego. Tym, co dodatkowo zbliżało polskich osadników do Słowaków, była religia katolicka. Mieszkający w okolicy Węgrzy byli przeważnie wyznania kalwińskiego. Rezultatem kontaktów z językiem słowackim jest m.in. konsekwentna realizacja głoski $r z$ jako $r$ oraz zapożyczone słownictwo, np. haluszki, lem, zahrada.

Wpływ języka węgierskiego na gwarę derenczan na większą skalę rozpoczął się dopiero, gdy zostali przesiedleni z Derenku i znaleźli się w otoczeniu Węgrów. Należy dodać, że w gwarach południowomałopolskich występują także zapożyczenia z języka słowackiego i węgierskiego, o których wspominaliśmy powyżej, np. bardo, baciar, gróf, retiazka / rzeciazka, rezać / rzezać, ryftar / ryftorz, sziuhaj. Warstwa słowackich naleciałości, a także wpływów języka węgierskiego zarówno na gwarę derenczan, jak i na gwary południowomałopolskie wymagałyby dokładnego zbadania przez językoznawców słowackich i węgierskich.

Po trzecie, warto jeszcze zastanowić się, jak to się stało, że taka etniczna wyspa przetrwała tyle lat $\mathrm{w}$ węgierskim otoczeniu? Na pewno sprzyjało temu przede wszystkim peryferyjne położenie wsi. Derenk był miejscem izolowanym, położonym w okolicy leśnej, z dala od ośrodków kultury węgierskiej. Najbliższa węgierska osada Szögliget była oddalona o pięć kilometrów na południe od wsi. Odosobnienie to sprzyjało kultywowaniu języka i obyczajów wyniesionych ze starego kraju.

Po czwarte, warto jeszcze wspomnieć o świadomości narodowej mieszkańców Derenku. Najstarsze pokolenie derenczan zachowało derencką świadomość, wypełnioną konkretnymi doświadczeniami związanymi z tamtym miejscem. 
Polskie pochodzenie dla byłych derenczan nie było początkowo takie oczywiste. Kiedy mówili o sobie, często używali nazwy tóth 'Słowak lub Słowianin', bo tak byli określani przez mieszkańców okolicznych wsi. O nasileniu świadomości polskości można mówić dopiero od lat 70. ubiegłego wieku dzięki upowszechnieniu badań historycznych na temat pochodzenia osadników z Derenku.

\section{LITERATURA}

Artowicz 1997 = Elżbieta Artowicz, Zbiorowość polska na Węgrzech i jej język, w: Język polski poza granicami kraju, red. Stanisław Dubisz, Opole: Uniwersytet Opolski, 1997, 145-161.

Bubenko-Greszkó 1998 = Waleria Bubenko-Greszkó, Polska gwara Derenczan na Węgrzech, Łódzkie Towarzystwo Naukowe 99 (1998), 215-219.

Dejna 1992 = Karol Dejna, Interferencje słowackie w polskiej gwarze na Węgrzech, w: Stowiańskie pogranicze językowe, red. Kwiryna Handke, Warszawa: Instytut Słowianoznawstwa PAN, 1992, 23-28.

Gotkiewicz 1962 = Marian Gotkiewicz, Migracje ludności polskiej po południowej stronie Karpat, Rocznik Naukowo Dydaktyczny WSP w Krakowie 1 (1962), 127-189.

Hemmert 1971 = Maria Hemmert, O polskiej gwarze wsi Istvánmajor na Węgrzech, Rozprawy Komisji Jezzkowej Wrocławskiego Towarzystwa Naukowego 8 (1971), 88-111.

Hemmert 1970 = Maria Hemmert, Gwara polska wsi Emöd Istvánmajor na Wegrzech, Szeged: Uniwersytet w Szegedzie, 1970 (maszynopis rozprawy doktorskiej).

Hemmert 1972 = Maria Hemmert, $\mathrm{O}$ wpływach leksykalnych języka węgierskiego na dialekt polski wsi Istvánmajor na Węgrzech, Język Polski 52 (1972), 369-373.

Hemmert-Udalska 1990 = Maria Hemmert-Udalska, Teksty gwary polskiej mieszkańców Istvánmajor na Węgrzech, Rozprawy Komisji Językowej Łódzkiego Towarzystwa Naukowego 35 (1990), 111-116.

Kantor - Krasińska 1981 = Ryszard Kantor - Ewa Krasińska, Potomkowie osadników z Polski we wsiach Derenk i Istvánmajor na Węgrzech 1: zarys gospodarki, 2: kultura spoleczna i duchowa, Kraków: Uniwersytet Jagielloński, 1981.

Kowalczyk - Kowalczyk - Łukuś 2014 = Anna Kowalczyk - Julian Kowalczyk - Elżbieta Łukuś, Stownik gwarowy mieszkańców Derenku i ich potomków = Derenki Lengyelek Góral Lengyel Magyar Szótára, Edelény: Stowarzyszenie Borsod-Torna-Gömör-Egyesület, 2014.

Kraszewski 1992 = Piotr Kraszewski, Polacy na Węgrzech, w: Polonia w Europie, red. Barbara Szydłowska-Ceglowa, Poznań: Polska Akademia Nauk - Zakład Badań Narodowościowych, $1992,551-558$.

Małecki 1938 = Mieczysław Małecki, Język polski na poludnie od Karpat, Kraków: Gebethner i Wolff, 1938.

Rémiás 2004 = Tibor Rémiás, In memoriam Derenk I: a derenki lengyelség nyomában: a temetökutatás redményei az egyházi halotti anyakönyvek alapján, Miskolc-Budapest, 2004.

Rémiás $\mathbf{2 0 0 5}$ = Tibor Rémiás, In memoriam Derenk II: a derenki lengyelség kapcsolatrendszere a házasultak gyházi könyvei tükrében, Miskolc-Budapest, 2005.

Rémiás $\mathbf{2 0 0 7}$ = Tibor Rémiás, In memoriam Derenk III: a derenki lengyelség nyomában az egyházi születési ill. keresztelési anyakönyvek alapján, Miskolc - Budapest, 2007.

Rémiás 2009 = Tibor Rémiás, Derenk: polska wieś góralska (monografia historyczna), tłum. Konrad Sutarski - Ewa Słaba Rónay, Miskolc: Dominium, 2009.

Reychman 1956 = Jan Reychman, Jeszcze o gwarach polskich na Węgrzech, Język Polski 36 (1956), 304-305.

Reychman 1966-1967 = Jan Reychman, Dzieje Polonii węgierskiej, Problemy Polonii Zagranicznej 5 (1966-1967), 47-62.

Stefańczyk 1995 = Wiesław Stefańczyk, Język Polonii węgierskiej: ujęcie typologiczne, Kraków: Uniwersytet Jagielloński, Instytut Polonijny, 1995. 
Stefańczyk 2013 = Wiesław Stefańczyk, Mniejszość polska na Węgrzech. Stan i potrzeby badań, Konteksty kultury 10 (2013), nr 4, 479-488.

Stieber 1950 = Zenon Stieber, Polska gwara na Węgrzech, Język Polski 30 (1950), 177-180.

Štolc 1949 = Jozef Štolc, Nárečie troch slovenských ostrovov v Mad’arsku, Bratislava: Slovenská akademia vied a umení, 1949, 431-439.

\section{POVZETEK}

\section{Jezilk potomcev poljskih kolonistov v Derenku na Madžarskem}

Članek obravnava glavne značilnosti v jeziku potomcev poljskih kolonistov na Madžarskem. Avtorica v njem ugotavlja, koliko se slovniški in slovarski pojavi navezujejo na poljska narečja.

Derenščina je samosvoj mešani kod s prvinami treh jezikov: poljščine, slovaščine in madžarščine. Podlaga tega koda je podhalsko-spiški govor. Na podhalsko-spiški izvor kažejo naslednji slovniški pojavi: mazurjenje, podhalska arhaičnost, začetni naglas, izgovor zoženih in nosnih samoglasnikov, prisotnost soglasnika $-k \mathrm{v}$ pregibnih končajih samostalnika, pridevnika, števnika, zaimka ter glagola in obrazila -uwać v nedoločnikih. $\mathrm{Na}$ leksikalni ravni nastopajo stari izrazi, ki jih srečujemo tudi v južnopoljskih govorih, npr. dziedzina, dziewka, miano, ka, krzesnomatka, podnozaje, parobek, świekier in zazbyrkać.

$\mathrm{Na}$ govor, ki so ga pred tremi stoletji prinesli z malopoljskega juga, sta vplivali slovaščina in madžarščina. Nasledek stikov s slovaščino je med drugim dosleden prehod glasu $r z \mathrm{v} r$ ter izposojenke kakor haluszki, lem, zahrada. Vpliv madžarščine je razviden na leksikalni ravni v besedah tipa atelepituwać, bardo, hejza in hotar. 